\title{
Effect of some Biostimulants Materials on Growth, Yield, Quality and Storability of Sweet Pepper.
}

\author{
S. A. Shehata ${ }^{1}$; M. EL- M. Saad ${ }^{2}$; M.A. Saleh' ${ }^{2}$ and S. A. Atala ${ }^{2}$ \\ ${ }^{1}$ Vegetable Crops Department, Faculty of Agriculture, Cairo University, Giza, Egypt. \\ ${ }^{2}$ Horticulture Research Institute, Agricultural Research Center, Giza, Egypt. \\ * Corresponding author: said_shehata2@yahoo.com
}

\begin{abstract}
This experiment was carried out under plastic house conditions during winter seasons of 2016 - 2017 and 2017 - 2018 in a clay loam at Agricultural Experiment Station, Faculty of Agriculture, Cairo University and Laboratory of Handling of Vegetable Crops Department, Horticulture Research Institute, Giza, to study the effect of some bio-stimulant, viz., seaweed extract (SWE) at $0.2 \%$, humic acid (HA) at $0.2 \%$ and biofertile (BF) at $2 \%$ as foliar spray as compared with untreated plants as control on vegetative growth, yield and its components, fruit quality and storability of sweet pepper fruits Monist $\mathrm{F}_{1}$ hybrid. Results indicated that plant treated with biofertile produced the highest value of all growth parameters (plant height, number of leaves/ plant and chlorophyll reading (SPAD) in leaves), yield and its component (fruit weight, number of fruits/ plant and total yield/ plot) and fruit quality (physical properties, viz., fruit length, flesh thickness and firmness and chemical properties viz., total soluble solids and ascorbic acid contents) followed by humic acid. Also, sweet pepper fruits obtained from plants treated with biofertile was the most effective treatment for improving storability and maintaining fruit quality attributes, which gave the lowest values of weight loss $\%$ and maintained fruit color, firmness, total soluble solids and ascorbic acid content and gave good appearance of fruits after 28 days of storage at $10^{\circ} \mathrm{C}$ and $95 \%$ relative humidity.
\end{abstract}

Key words: sweet pepper, bio-stimulants, seaweed extract, humic acid, biofertile, vegetative growth, yield, quality, storability.

\section{Introduction}

Sweet pepper plant (Capsicum annuum L.) is the third most important crop of Solanaceae family after tomatoes and potatoes. Pepper is one of the richest vegetable in vitamin $\mathrm{C}$. It also contains a good amount of vitamin $\mathrm{A}, \mathrm{B}_{1}$ and other vitamins which are essential for growth (McCollum, 1980). To improve the sweet pepper fruits quality and quantity in the field, maintain their quality after harvest and increase their shelf life, several investigations have been conducted on pre-harvest treatments through using some bio-stimulants, i.e., seaweed extract, humic acid and biofertile which should improve physical, chemical and biological properties and increase soil organic matter, carbon exchange capacity, available mineral nutrients ( Marhoon and Abbas, 2015 for seaweed extract; Fathima and Denesh, 2013 for humic acid and Nuruzzaman et al., 2003 for biofertilizer) and this in turn, stimulates quantitative as well as qualitative characteristics and improves storability of sweet pepper.

Seaweed extracts have been marketed for several years as fertilizer additives and beneficial results from their use have been reported (Booth, 1965). Booth (1969) observed that the value of seaweeds as fertilizers was not only due to nitrogen, phosphorus and potash content, but also because of the presence of trace elements and metabolites. These extracts enhance seed germination, growth, yield and uptake of nutrients by the plants. The extract also contends hormones (IAA and IBA), cytokinins, trace elements ( $\mathrm{Fe}, \mathrm{Cu}, \mathrm{Zn}, \mathrm{Co}, \mathrm{Mo}, \mathrm{Mn}$, $\mathrm{Ni}$ ), vitamins and amino acids (Challen and Hemingway, 1965). Thus, these extracts stimulate growth of the plants (Blunden et al., 1996). In studies conducted by Demir et al. (2006) and Mohammed (2013) on pepper plants using of seaweed extract as a foliar spray on shoot, they found significant increase in plant height and percentage of total chlorophyll.

Humic acid has ability to promote hormonal activity in plants and promote plant health, plant growth, nutrient uptake and also improves stress tolerance (Atiyeh et al., 2002). The significance of humic acids is not limited to their function as a reservoir of mineral plant nutrients and regulator of their liberation. Recent literature has shown that humic acid could be used as a growth regulator to regulate hormone levels, improve plant growth and enhance stress tolerance (Serenella et al., 2002). Humic substances are generated through organic matter decomposition and employed as soil fertilizers in order to improve soil structure and soil microorganisms (Karakurt et al., 2009 and Halime et al., 2011). Abd El-Basir (2013) showed that spraying sweet pepper plants with humic acid led to positive significant differences in fruits number, early and total yield as well as fruit weight, fruit length, yield per plant, fruit dry weight, fruit chlorophyll content and TSS percentage as compared to untreated plants.

Bio fertilizers have been considered as a cheap, eco-friendly way of improving soil fertility status. N- 
fixing bacteria possess unique potential of fixing atmospheric nitrogen either by living symbiotically or non-symbiotically or to transform native soil nutrients, from non-usable to usable form through biological process (Marwaha, 1995). Azotobacter and Azospirillum are the two most important nonsymbiotic $\mathrm{N}_{2}$-fixing bacteria and considered to be very important for fixation of nitrogen in nonleguminous crops. Besides $\mathrm{N}_{2}$ fixation, Azotobacter synthesizes and secretes considerable amounts of biologically active substances like B vitamins, nicotinic acid, pantothenic acid, biotin, heteroxins, gibberellins etc. which enhance root growth of plants (Mishutin, 1970 and Rao et al., 1986). Another important characteristic of Azotobacter association with crop improvement is excretion of ammonia in the rhizosphere in the presence of root exudates, which helps in modification of nutrient uptake by the plants (Narula and Gupta, 1986). The ability of Azospirillum to produce plant growth regulatory substances along with $\mathrm{N}_{2}$-fixation stimulate growth and thereby productivity. The changes occur in the plant roots help in transport of minerals and water (Sarig et al., 1988). All these factors combined together produce positive effects on crop yield especially for cereals and vegetables. Furthermore, Azotobacter and Azospirillum have also been found to promote synthesis of growth promoting substances like auxins, gibberellins, cytokinins and antibiotic metabolites which, in turn, improved resistance against biotic and abiotic stress (Awasthi et al., 1998).
The objective of this work were to study the effect of seaweed extract, humic acid and biofertile as foliar spray on vegetative growth, yield and its components, fruit quality and storability of sweet pepper fruits.

\section{Material and Methods}

This experiment was carried out under plastic house conditions during winter seasons of 2016-2017 and 2017-2018 at Agricultural Experiment Station, Faculty of Agriculture, Cairo University to study the effect of some bio-stimulants, viz., seaweed extract (SWE) at $0.2 \%$, humic acid (HA) at $0.2 \%$ and biofertile (BF) at $2 \%$ as foliar spray as compared with untreated plants (spray with water only) as control on vegetative growth parameters, yield and its components, fruit quality and storability of sweet pepper fruits Monist $F_{1}$ hybrid.. The physical and chemical properties of the clay loam soil under study (Table 1) were determined at the Soil and Water Research Institute, Agricultural Research Center. Seeds of sweet pepper (Capsicum annuum L.) Monist $F_{1}$ hybrid were sown at the nursery on $7^{\text {th }}$ and $14^{\text {th }}$ of September in 2016 and 2017 seasons, respectively, and seedlings were transplanted on $16^{\text {th }}$ and $21^{\text {st }}$ of October in the first and second season, respectively.

The plastic house was $40 \mathrm{~m}$ long and $8 \mathrm{~m}$ wide $\left(320 \mathrm{~m}^{2}\right)$ and divided into five beds, each $1 \mathrm{~m}$ wide and $40 \mathrm{~m}$ long. The experiment occupied three beds. Seedling were planted on the two sides of each bed and $50 \mathrm{~cm}$ apart.

Table 1. Physical and chemical characteristics of experimental soil as average of both seasons 2016 and 2017.

Physical properties

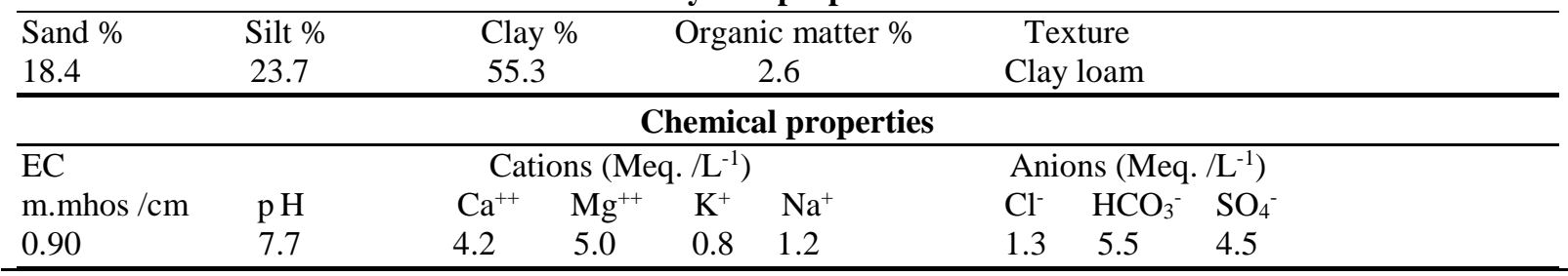

Seaweed extract (Oligo- $\mathrm{X}$ as commercial name) was obtained from Union for Agriculture Development (UAD) Company, Cairo, Egypt; it contains organic matter (6\% total amino acid, $35 \%$ carbohydrate, $10 \%$ alginic acid, $4 \%$ mannitol, $0.04 \%$ betaines); growth regulators $(0.03 \%$ IAA, $0.02 \%$ cytokinins (adenine)) and some macro and microelements $\left(3.12 \% \mathrm{~N}, 2.61 \% \mathrm{P}_{2} \mathrm{O}_{5}, 4.71 \% \mathrm{k}_{2} \mathrm{O}\right.$, $0.25 \% \mathrm{Ca}, 3.56 \% \mathrm{~S}$ and $0.58 \% \mathrm{Mg}$ ). Humic acid (HA) [Hammar, Arabian Group of Agricultural Service (AGAS), Egypt; it contains potassium humate $86 \%$ and potassium oxide $6 \%$ ]. Biofertile preparation, developed at the Environmental Studies and Research Unit (ESRU), Faculty of Agriculture, Cairo University, are composites of rhizobacterial strains supporting plant nutrition (Table 2) is a mixture of rhizobacterial isolates of diazotrophic nature, i.e. efficient in biological nitrogen fixation and production of auxins, mainly gibrillic acid (Othman et al. 2003, 2004). These strains with their host plants are presented in Table (2).

The experiment included four treatments as follow

1 - Seaweed extract (SEW) at $0.2 \%$.

2- Humic acid (HA) at $0.2 \%$.

3- Biofertile at $2 \%$.

4- Untreated plants (control).

These treatments were applied (as foliar spray) four times during the growing period of sweet pepper plants at 30, 40, 50 and 60 days after transplanting.

The previous treatments were arranged in a complete randomized block design with three 
replicates. The area of each experimental unit is 10 $\mathrm{m}^{2}$ with 40 plants. The recommended agricultural practices for commercial sweet pepper production, i.e., drip irrigation; fertilization and weed control were followed according to Ministry of Agriculture recommendations.

Table 2. Rhizobacterial isolates in biofertile and their host plants.

\begin{tabular}{l} 
Bacterial isolates (diazotrophs) \\
Azospirillum brasilense \\
Azotobacter chroocooccum \\
Bacillus polymyxa \\
Enterobacter agglomerans \\
Pesudomonas putida \\
\hline
\end{tabular}

Data were recorded as follow:

A-Vegetative growth:

A representative sample of 5 plants was chosen at random, 65 days after transplanting, from each experimental plot for measuring plant growth parameters, viz., plant height and number of leaves per plant. Chlorophyll reading of the sixth mature leaf was measured in SPAD unit, where SPAD $=10$ $\mathrm{mg}$ chlorophyll /g fresh weight using digital chlorophyll meter (Model Minolta chlorophyll meter SPAD-502) which is presented by SPAD value. Average of 3 measurements from different spots of a single leave was considered.

\section{B-Yield and its components:}

At harvesting time (70 days from transplanting), sweet pepper fruits were picked weekly through the harvesting period till the last week of May for estimation of yield parameters, viz., total number of fruits/ plant, fruit weight/ plant and total yield $\mathrm{Kg}$ / plot (determined for all pickings and calculated as total fresh weight of fruits).

\section{C- Fruit quality:}

A random sample of 10 fruits from each replicate was taken at harvest and the following characters were measured: fruit length, fruit diameter, fruit firmness, flesh thickness, color change ( $\mathrm{L}$ and $\mathrm{b}$ value), total soluble solids \% and vitamin $\mathrm{C}$ content.

\section{Storage experiment:}

Fruits of sweet pepper for each treatment were harvested at $3 / 4$ yellow color stage on $2^{\text {nd }}$ and $4^{\text {th }}$ of February in 2017 and 2018 seasons, respectively, and then transferred to laboratory of Handling of Vegetable Crops Department, Horticultural Research Institute at Giza. Samples were selected for their uniformity of size (about $280 \pm 10 \mathrm{gm}$ each fruit) and free of visual damage defects. All samples for preharvest treatments of sweet pepper fruits were placed in polypropylene bags $(25 \times 35 \mathrm{~cm})$ and $40 \mu$ thickness. Each bag contains 3 fruits represented as one replicate. Twenty four replicates were prepared from each treatment and stored at $10^{\circ} \mathrm{C}$ and $95 \%$ relative humidity (RH). Samples were taken randomly in three replicates from each treatment and were arranged in complete randomized design. Measurements were done immediately after harvest

Host plants and reference
Ricinus communis L. (Hamza et al.,1994
Hordeum vulgare (Ali et al. 2005)
Hamada elegans (Hegazi and Fayez, 2003)
Malva parviflora (Hegazi and Fayez, 2003)
Sorghum biocolor (Hamza et al.,1994)

and at 7 days intervals ( $0,7,14,21$ and 28 days) of storage at $10^{\circ} \mathrm{C}$ for the following properties:

- Weight loss percentage was estimated according to the following equation:

Weight loss $\%=\frac{\text { Initial weight of fruits }- \text { weight at sampling date }}{\text { Initial weight of fruits }} \times 100$

- General appearance was measured on score rating from 9 to 1 , where $9=$ excellent, $7=$ good, 5 = fair, $3=$ poor and $1=$ unsalable.

- Surface color was measured on two sides of each fruit by using Tistimulus Hunter Colorimeter Minolta, Ramsey, N.J. (Model Dp 9000 which measured L* value and b value) (McGuire, 1992).

- $\quad$ Fruit firmness was measured by a hand pressure tester (Italian model) expressed in $\mathrm{kg} / \mathrm{cm}^{2}$.

- Total soluble solids percentage (TSS) was determined by using refractometer according to AOAC (2000).

- Ascorbic acid content (mg /100 g fruit fresh weight) was determined by titration method using 2, 6 dichloro-phenole-endo-phenole (AOAC, 2000).

\section{Statistical analysis:}

Data were statistically analyzed using the analysis of variance described by Snedecor and Cochran (1980). The method of Duncan multiple range tests were applied for than comparison between means according to Waller and Duncan (1969).

\section{Result and Discussion}

\section{Vegetative growth}

Data in Table (3) showed that sweet pepper plants treated with all pre-harvest treatments had a significantly increased on all studied vegetative growth parameters compared to untreated plants (control) treatments. In this respect; plants treated with biofertile produced the highest value of all growth parameters (plant height, number of leaves/ plant and chlorophyll reading (SPAD) in leaves) followed by plant treated with humic acid (HA) with significant difference between them, plant treated with seaweed extract (SEW) was less effective in this concern. On the other hand, the lowest values in this respect were recorded in untreated plants (control) 
treatment. These results were true in the two seasons and in agreement with Abd EL-Basir (2013) for seaweed extract or humic acid on sweet pepper and Singh and Singh (2009) for biofertile on strawberry. The enhance effect of biofirtizer on crop growth and yield may be due to the activity of photosynthetic bacteria such as Azospirillum, Azotobacter and Pseudomonas present in biofirtizer solution. These bacteria are a group of independent, self-supporting microbes. They synthesize useful substances from secretions of plant roots, organic matter and harmful gases such as hydrogen sulfide, by using sunlight and the heat of soil as sources of energy (Kim et al., 2004). The useful substances produced by these bacteria include protein, fat, amino acids, polysaccharides, bioactive substances and sugars, all of which promote plant growth and development. The increment in vegetative growth of sweet pepper plants by adding HA to the plant may be due to that HA containing the most of the known trace minerals necessary to the development of plant life (Senn, 1991). It enhances soil fertility and improves physical, chemical and biological properties of soil (Mikkelsen, 2005), like permeability, aeration, aggregation, water capacity, ion transport and availability through $\mathrm{pH}$ buffering (Selim et al., 2010). There effects may result in greater plant growth with HA application (Gad EL-Hak et al., 2012). The beneficial effect of seaweed extract on plant growth may be due to the composition of the seaweed extract such as natural growth hormones (auxins and cytokinins) that promote plant growth via increasing a number of metabolic events which in turn leading to increase plant growth (Demir et al., 2006; Gallon and Wright, 2006 and Prasad et al., 2010). In addition, the extract contains a considerable amount of macro and micro elements which play an important role in the activation of many enzymes and coenzymes which are involved in several biological processes leading to cell division and enlargement (Murugalakshmikumari et al., 2002 and Anantharaj and Venkatesalu, 2002) improved total chlorophyll in leaves (Al-Sahaff, 1989) .

Table 3: Effect of some bio-stimulants on vegetative growth of sweet pepper during 2016 - 2017 and 2017 2018 seasons.

\begin{tabular}{lcccccc}
\hline \multirow{2}{*}{ Treatments } & \multicolumn{2}{c}{ plant height $(\mathbf{c m})$} & \multicolumn{2}{c}{ No. of leaves / plant } & \multicolumn{3}{c}{ chlorophyll (SPAD) } \\
& $\mathbf{2 0 1 6}$ & $\mathbf{2 0 1 7}$ & $\mathbf{2 0 1 6}$ & $\mathbf{2 0 1 7}$ & $\mathbf{2 0 1 6}$ & $\mathbf{2 0 1 7}$ \\
\hline Seaweed extracts $(\mathbf{0 . 2} \%)$ & $67.24 \mathrm{C}$ & $69.34 \mathrm{C}$ & $158.20 \mathrm{C}$ & $161.30 \mathrm{C}$ & $36.23 \mathrm{C}$ & $37.35 \mathrm{C}$ \\
Humic acid $(\mathbf{0 . 2 \%})$ & $72.82 \mathrm{~B}$ & $75.32 \mathrm{~B}$ & $164.30 \mathrm{~B}$ & $167.80 \mathrm{~B}$ & $38.79 \mathrm{~B}$ & $39.94 \mathrm{~B}$ \\
Biofertile (2\%) & $80.11 \mathrm{~A}$ & $83.21 \mathrm{~A}$ & $172.10 \mathrm{~A}$ & $176.10 \mathrm{~A}$ & $41.13 \mathrm{~A}$ & $42.33 \mathrm{~A}$ \\
Control & 61.23 D & 62.93 D & 150.10 D & 152.40 D & 32.36 D & $33.57 \mathrm{D}$ \\
\hline
\end{tabular}

Means in the same column having the same letter are not significantly different at 0.05 levels by Duncan's multiple rang test.

\section{Yield and its component}

Data in Table (4) showed that sweet pepper plants treated with seaweed extract (SEW), humic acid (HA) and biofertile had significantly increased fruit weight, number of fruits/ plant and total yield/ plot compared to control plants. However, plants treated with biofertile was the most effective treatment for enhancing fruit weight (270.11 and $274.31 \mathrm{gm})$ number of fruits per plant (17.40 and 18.57) and total yield per plot (187.90 and 202.31 $\mathrm{kg}$ ) in the first and second seasons respectively, followed by plants treated with humic acid (HA) with significant differences between them in the two seasons. The increase in yield was due to increases in number of fruits as well as fruit weight, while the lowest value in this respect were recorded in the untreated plants ( control). The results were true in the two seasons and in agreement with Abd EL-Basir (2013) for seaweed extract or humic acid on sweet pepper and Singh and Singh (2009) for biofertile for strawberry. The beneficial effect of biofertilizer application on yield may be due to Azotobacter and
Azospirillum treatments have positive effect on flower formation; fruit set and thus increase the total yield. This increased fruit set and yield may be due to the fact that nitrogen fixer not only increased the availability of nitrogen to the plant roots but also increased their translocation from root to flower through plants foliage. The enhancing effect of humic acid on yield and its components could be explained as humic acid is rich in both organic and mineral substances which are essential to plant growth and consequently increase yield quality and quantity (GadEl-Hak et al., 2012). Also, humic acid enhancing effect on increase soil moisture holding capacity, improve soil texture as well as promote the uptake of nutrients leading to stimulation of plant growth and consequently on total pods yield and its components (Zhang et al., 2003). The beneficial effect of seaweed extract application on yield and its components of sweet pepper may be due to the increasing in vegetative growth parameters, also increase in number of pods as well as weight of pods per plant (Abou El-Yazied et al., 2012 and Khan et al., 2009) found that treatment with seaweed 
extracts on yield has enhancement effects due to improved chlorophyll content in leaves of various crop plants have been attributed to the betaines present in seaweed, yield increases in seaweedtreated plants are thought to be associated with the hormonal substances present in the extracts, especially cytokinins; cytokinins in vegetative plant organs are associated with nutrient partitioning, whereas in reproductive organs, high levels of cytokinins may be linked with nutrient.

Table 4. Effect of some bio-stimulants on total yield and its components of sweet pepper plants during 20162017 and 2017-2018 seasons.

\begin{tabular}{lllllll}
\hline \multirow{2}{*}{ Treatments } & \multicolumn{2}{c}{ Fruit weight $\mathbf{( g m )}$} & \multicolumn{2}{c}{ No. of fruit / plant } & \multicolumn{2}{c}{ Total yield / plot (kg) } \\
\cline { 2 - 7 } & $\mathbf{2 0 1 6}-\mathbf{2 0 1 7}$ & $\mathbf{2 0 1 7 - 2 0 1 8}$ & $\mathbf{2 0 1 6}-\mathbf{2 0 1 7}$ & $\mathbf{2 0 1 7 - 2 0 1 8}$ & $\mathbf{2 0 1 6 - 2 0 1 7}$ & $\mathbf{2 0 1 7 - 2 0 1 8}$ \\
\hline Seaweed extracts (0.2 \%) & $244.80 \mathrm{C}$ & $246.71 \mathrm{C}$ & $15.64 \mathrm{C}$ & $16.74 \mathrm{C}$ & $153.40 \mathrm{C}$ & $165.41 \mathrm{C}$ \\
Humic acid (0.2\%) & $255.30 \mathrm{~B}$ & $251.32 \mathrm{~B}$ & $16.49 \mathrm{~B}$ & $17.79 \mathrm{~B}$ & $168.20 \mathrm{~B}$ & $179.40 \mathrm{~B}$ \\
Biofertile (2\%) & $270.11 \mathrm{~A}$ & $274.31 \mathrm{~A}$ & $17.40 \mathrm{~A}$ & $18.57 \mathrm{~A}$ & $187.90 \mathrm{~A}$ & $202.31 \mathrm{~A}$ \\
Control & $236.12 \mathrm{D}$ & $238.66 \mathrm{D}$ & $14.23 \mathrm{D}$ & $15.00 \mathrm{D}$ & $134.40 \mathrm{D}$ & $140.40 \mathrm{D}$
\end{tabular}

Means in the same column having the same letter are not significantly different at 0.05 level by Duncan's multiple rang test.

\section{Fruit quality}

Data in Table (5) showed that all preharvest applications significantly increased fruit physical properties (fruit length, flesh thickness and firmness) and chemical properties (total soluble solids and ascorbic acid contents) compared with fruits obtained from untreated plants. In this respect, sweet pepper fruits obtained from plants treated with biofertile had the best fruit quality, followed by humic acid (HA) with no significant differences between them in these characters except flesh thickness and fruit firmness. The least value of these characters was in the untreated plants. However, concerning fruit diameter, there was no significant differences between all pre-harvest treatments and control. These results were achieved in the two seasons and were in agreement with those obtained by Abd EL-Basir (2013) for seaweed extract or humic acid on sweet pepper and Singh and Singh (2009) for biofertile for strawberry. The application of nitrogen fixing bacteria with lower dose of nitrogen application might have exhibited regulatory role on the absorption and translocation of various metabolites, in which carbohydrates are most important which affects the quality of fruits. During ripening of fruits the carbohydrates reserves of the root and stem are drawn upon heavily and hydrolysed into sugars. Terry et al. (2000) who reported the increased translocation of assimilates from leaves to the developing fruit.

Table 5. Effect of some bio-stimulates on physical and chemical properties of sweet pepper fruits during 20162017 and 2017-2018 seasons.

\begin{tabular}{|c|c|c|c|c|c|c|}
\hline Treatments & $\begin{array}{c}\text { Fruit length } \\
(\mathrm{cm})\end{array}$ & $\begin{array}{l}\text { Fruit diameter } \\
\text { (cm) }\end{array}$ & $\begin{array}{c}\text { Flesh thickness } \\
\text { fruits (mm) }\end{array}$ & $\begin{array}{l}\text { Firmness } \\
\left(\mathrm{kg} / \mathrm{cm}^{2}\right)\end{array}$ & TSS (\%) & $\begin{array}{c}\text { Ascorbic acid } \\
(\mathrm{mg} / 100 \mathrm{FW})\end{array}$ \\
\hline \multicolumn{7}{|c|}{ Season $2016 / 2017$} \\
\hline $\begin{array}{l}\text { Seaweed extracts } \\
(0.2 \%)\end{array}$ & $7.36 \mathrm{BC}$ & $7.10 \mathrm{~A}$ & $7.08 \mathrm{C}$ & $1.75 \mathrm{C}$ & $7.60 \mathrm{~B}$ & $288.20 \mathrm{BC}$ \\
\hline Humic acid $(0.2 \%)$ & $7.74 \mathrm{AB}$ & $7.17 \mathrm{~A}$ & $7.20 \mathrm{~B}$ & $1.95 \mathrm{~B}$ & $8.40 \mathrm{~A}$ & $294.80 \mathrm{AB}$ \\
\hline Biofertile (2\%) & $8.04 \mathrm{~A}$ & $7.21 \mathrm{~A}$ & $7.32 \mathrm{~A}$ & $2.08 \mathrm{~A}$ & $8.50 \mathrm{~A}$ & $299.20 \mathrm{~A}$ \\
\hline Control & $7.00 \mathrm{C}$ & $7.00 \mathrm{~A}$ & $6.86 \mathrm{D}$ & $1.50 \mathrm{D}$ & $6.80 \mathrm{C}$ & $279.50 \mathrm{C}$ \\
\hline \multicolumn{7}{|c|}{ Season $2017 / 2018$} \\
\hline $\begin{array}{l}\text { Seaweed extracts } \\
(0.2 \%)\end{array}$ & $7.50 \mathrm{~B}$ & $7.22 \mathrm{~A}$ & $7.22 \mathrm{C}$ & $2.11 \mathrm{C}$ & $7.10 \mathrm{CF}$ & 291.30 B \\
\hline Humic acid $(0.2 \%)$ & $7.93 \mathrm{~A}$ & $7.31 \mathrm{~A}$ & $7.37 \mathrm{~B}$ & $2.27 \mathrm{~B}$ & $8.10 \mathrm{AB}$ & $298.80 \mathrm{AB}$ \\
\hline Biofertile (2\%) & $8.27 \mathrm{~A}$ & $7.38 \mathrm{~A}$ & $7.51 \mathrm{~A}$ & $2.40 \mathrm{~A}$ & $8.53 \mathrm{~A}$ & $303.70 \mathrm{~A}$ \\
\hline Control & $7.10 \mathrm{~B}$ & $7.08 \mathrm{~A}$ & $6.95 \mathrm{D}$ & $1.89 \mathrm{D}$ & $6.10 \mathrm{GJ}$ & $281.80 \mathrm{C}$ \\
\hline
\end{tabular}

Means is the same column having the same letter are not significant different at 0.05 level by Duncan's multiple rang test.

\section{Weight loss percentage}

Data in Table (6) show that weight loss percentage of sweet pepper fruits increased considerably and consistently with the prolongation of storage period. These results are in agreement with those obtained by Gad EL-Rab (2013) on pepper and may be due to its respiratory processes, and other senescence related metabolic processes during storage (Neill et al., 2002). All pre-harvest treatments gave significant lower weight loss 
percentage of fruits compared to untreated (control); however, sweet pepper fruits obtained from plants treated with biofertile surpassed those fruits obtained from the other treatments or untreated (control) in minimizing fruit weight loss percentage during storage followed by humic acid (HA) with significant difference between them in the two seasons. Fruits obtained from seaweed extract (SEW) were less effective in reducing the loss of weight percentage. On the contrary, fruits obtained from untreated plants gave the highest values of weight loss percentage. These results were achieved in the two seasons and were in agreement with those obtained by Gad ELRab (2018) for humic acid and seaweed extract on snap bean and Hassan and Emam (2015) for biofertile on strawberry. The beneficial effect of HA or biofertile on reducing weight loss $\%$ in fruits during storage may be attributed to the role of such natural anti disease substances in decreasing the susceptibility for diseases infection, decreasing the respiration rate and production of ethylene which affects greatly fruit storage ability (Gad EL-Rab, 2018 for HA and seaweed extract and Hassan and Emam, 2015 for biofertile). Such results may be due to the beneficial effect of seaweed extract or humic acid (Abd El-Basir, 2013) and biofertile (Hassan and Emam, 2015) on vegetative growth and chemical composition of sweet pepper fruits which in turn maintained the metabolic homeostasis after harvest and reduce dehydration of fruits. In general, the interaction between pre-harvest treatments and storage period was significant effect on the both seasons. After 28 days of storage, sweet pepper fruits obtained from plants treated with biofertile showed the least weight loss percentage, while untreated content gave the lowest value. These results were true in the two seasons.

Table 6. Effect of some bio-stimulants on weight loss \% of sweet pepper fruits during storage in 2016-2017 and 2017-2018 seasons.

\begin{tabular}{|c|c|c|c|c|c|c|}
\hline \multirow{2}{*}{ Treatments } & \multicolumn{5}{|c|}{ Storage period in days } & \multirow{2}{*}{ means } \\
\hline & Start & 7 & 14 & 21 & 28 & \\
\hline \multicolumn{7}{|c|}{ season $2016 / 2017$} \\
\hline Seaweed extracts $(0.2 \%)$ & $0.00 \mathrm{M}$ & $0.76 \mathrm{JK}$ & $1.57 \mathrm{FG}$ & $1.93 \mathrm{CD}$ & $2.17 \mathrm{~B}$ & $1.29 \mathrm{~B}$ \\
\hline Humic acid $(0.2 \%)$ & $0.00 \mathrm{M}$ & $0.66 \mathrm{KL}$ & $1.40 \mathrm{HI}$ & $1.72 \mathrm{EF}$ & $1.98 \mathrm{C}$ & $1.15 \mathrm{C}$ \\
\hline Biofertile (2\%) & $0.00 \mathrm{M}$ & $0.57 \mathrm{~L}$ & $1.23 \mathrm{I}$ & $1.51 \mathrm{GH}$ & $1.76 \mathrm{DE}$ & $1.01 \mathrm{D}$ \\
\hline Control & $0.00 \mathrm{M}$ & $0.90 \mathrm{~J}$ & $1.68 \mathrm{EF}$ & $2.21 \mathrm{~B}$ & $2.50 \mathrm{~A}$ & $1.46 \mathrm{~A}$ \\
\hline means & $0.00 \mathrm{E}$ & $0.73 \mathrm{D}$ & $1.47 \mathrm{C}$ & $1.84 \mathrm{~B}$ & $2.10 \mathrm{~A}$ & \\
\hline \multicolumn{7}{|c|}{ season $2017 / 2018$} \\
\hline Seaweed extracts $(0.2 \%)$ & $0.00 \mathrm{~K}$ & $0.73 \mathrm{IJ}$ & $1.54 \mathrm{FG}$ & $1.90 \mathrm{CD}$ & $2.14 \mathrm{~B}$ & $1.26 \mathrm{~B}$ \\
\hline Humic acid $(0.2 \%)$ & $0.00 \mathrm{~K}$ & $0.63 \mathrm{~J}$ & $1.39 \mathrm{G}$ & $1.69 \mathrm{EF}$ & $1.94 \mathrm{C}$ & $1.13 \mathrm{C}$ \\
\hline Biofertile (2\%) & $0.00 \mathrm{~K}$ & $0.55 \mathrm{~J}$ & $1.21 \mathrm{H}$ & $1.52 \mathrm{FG}$ & 1.74 DE & $1.00 \mathrm{D}$ \\
\hline Control & $0.00 \mathrm{~K}$ & $0.89 \mathrm{I}$ & $1.67 \mathrm{EF}$ & $2.20 \mathrm{~B}$ & $2.49 \mathrm{~A}$ & $1.45 \mathrm{~A}$ \\
\hline means & $0.00 \mathrm{E}$ & $0.70 \mathrm{D}$ & $1.45 \mathrm{C}$ & $1.83 \mathrm{~B}$ & $2.08 \mathrm{~A}$ & \\
\hline
\end{tabular}

Means in the same column having the same letter are not significantly different at 0.05 level by Duncan's multiple rang test.

\section{General appearance}

Data in Table (7) show that general appearance of sweet pepper fruits decreased with the prolongation of storage period at $10^{\circ} \mathrm{C}$. Similar results were reported by Gad EL-Rab (2013) on pepper. The decreases in GA during storage period might be due to shriveling, wilting, color change and decay (Banaras et al., 2005). All pre-harvest treatments had the higher score of GA when compared with the untreated plants (control) during storage, however, sweet pepper fruits obtained from plants treated with biofertile gave the highest score of GA of fruits, followed by humic acid (HA) treatments with significant difference between them in the two seasons. The worst GA was recorded for the untreated control. These results were achieved in the two seasons and were in agreement with those obtained by Gad EL-Rab (2018) for seaweed extract and HA on snap bean, Hassan and Emam (2015) for biofertile on strawberry. The enhancement effect in both seasons might be attributed to that SWE, HA and biofertile materials contains nutrient elements and organic compounds (Nagodawithana, 1991), macro and micro elements (Khan et al., 2009) and rich in both organic and mineral substances (Gad ELHak et al., 2012), these minerals (potassium, calcium, iron, manganese and magnesium) reducing weight loss percentage and maintaining green color during storage (Shehata et al., 2015). The interaction between pre-harvest treatments and storage period was significant in the two seasons; however, sweet pepper fruits obtained from plants treated with biofertile did not exhibit any changes in their appearance till 21 days at $10^{\circ} \mathrm{C}$ and gave good appearance after 28 days of storage, while, fruits obtained from plants treated with humic acid (HA) or seaweed extract rated good appearance after 21 days of storage, while fruits which obtained from untreated control rated the unsalable appearance at the end of storage (28 days) in the two seasons. 
Table 7. Effect of some bio-stimulants on general appearance (score) of sweet pepper fruits during storage in 2016-2017 and 2017-2018 seasons.

\begin{tabular}{|c|c|c|c|c|c|c|}
\hline \multirow{2}{*}{ Treatments } & \multicolumn{5}{|c|}{ Storage period in days } & \multirow{2}{*}{ means } \\
\hline & Start & 7 & 14 & 21 & 28 & \\
\hline \multicolumn{7}{|c|}{ season $2016 / 2017$} \\
\hline Seaweed extracts $(0.2 \%)$ & $9.00 \mathrm{~A}$ & $9.00 \mathrm{~A}$ & $7.67 \mathrm{BC}$ & $7.00 \mathrm{CD}$ & $5.67 \mathrm{EF}$ & $7.53 \mathrm{C}$ \\
\hline Humic acid $(0.2 \%)$ & $9.00 \mathrm{~A}$ & $9.00 \mathrm{~A}$ & $9.00 \mathrm{~A}$ & 7.67 BC & $6.33 \mathrm{DE}$ & $8.07 \mathrm{~B}$ \\
\hline Biofertile (2\%) & $9.00 \mathrm{~A}$ & $9.00 \mathrm{~A}$ & $9.00 \mathrm{~A}$ & $8.33 \mathrm{AB}$ & $7.67 \mathrm{BC}$ & $8.60 \mathrm{~A}$ \\
\hline Control & $9.00 \mathrm{~A}$ & $8.33 \mathrm{AB}$ & $7.00 \mathrm{CD}$ & $5.00 \mathrm{~F}$ & $3.00 \mathrm{G}$ & $6.47 \mathrm{D}$ \\
\hline Means & $9.00 \mathrm{~A}$ & $8.83 \mathrm{~A}$ & 8.17 B & $7.00 \mathrm{C}$ & $5.67 \mathrm{D}$ & \\
\hline \multicolumn{7}{|c|}{ season $2017 / 2018$} \\
\hline Seaweed extracts $(0.2 \%)$ & $9.00 \mathrm{~A}$ & $9.00 \mathrm{~A}$ & $8.33 \mathrm{AB}$ & $7.00 \mathrm{CD}$ & $5.67 \mathrm{C}$ & $7.67 \mathrm{~B}$ \\
\hline Humic acid (0.2\%) & $9.00 \mathrm{~A}$ & $9.00 \mathrm{~A}$ & $9.00 \mathrm{~A}$ & $7.67 \mathrm{BC}$ & $6.33 \mathrm{C}$ & $8.07 \mathrm{~B}$ \\
\hline Biofertile (2\%) & $9.00 \mathrm{~A}$ & $9.00 \mathrm{~A}$ & $9.00 \mathrm{~A}$ & $9.00 \mathrm{~A}$ & $8.33 \mathrm{AB}$ & $8.87 \mathrm{~A}$ \\
\hline Control & $9.00 \mathrm{~A}$ & $9.00 \mathrm{~A}$ & $7.00 \mathrm{BC}$ & $5.67 \mathrm{C}$ & $3.67 \mathrm{D}$ & $6.87 \mathrm{C}$ \\
\hline Means & $9.00 \mathrm{~A}$ & $9.00 \mathrm{~A}$ & $8.33 \mathrm{~A}$ & $7.34 \mathrm{~B}$ & $6.00 \mathrm{C}$ & \\
\hline
\end{tabular}

Means in the same column having the same letter are not significantly different at 0.05 level by Duncan's multiple rang test.

\section{Color ( $L$ value)}

Data in Table (8) showed that $\mathrm{L}$ value of fruits was significantly decreased with the progress of storage period in the two seasons indicating that darker color. These results were true in the two seasons and were in agreement with Gad EL-Rab (2013). Concerning the effect of pre-harvest treatments, results indicating that all pre-harvest treatments had the highest $\mathrm{L}$ value when compared with the fruits obtained from untreated plants (control) during storage. However, the highest L value was detected in sweet pepper fruits obtained from biofertile or humic acid (HA) indicating that, lighter color with no significant difference between them in the first season, while the lowest $\mathrm{L}$ value was recorded in fruits obtained from untreated plants (control), indicated that darker color. These results were in agreement with Gad EL-Rab (2018) for SWE or humic acid.

Table 8. Effect of some bio-stimulants on color (L. value) of sweet pepper fruits during storage in 2016-2017 and 2017-2018 seasons.

\begin{tabular}{|c|c|c|c|c|c|c|}
\hline \multirow{2}{*}{ Treatments } & \multicolumn{5}{|c|}{ Storage period in days } & \multirow{2}{*}{ Means } \\
\hline & Start & 7 & 14 & 21 & 28 & \\
\hline \multicolumn{7}{|c|}{ season $2016 / 2017$} \\
\hline $\begin{array}{l}\text { Seaweed extracts }(0.2 \\
\%)\end{array}$ & $57.16 \mathrm{AC}$ & 56.77 ACD & $55.40 \mathrm{ACD}$ & $54.00 \mathrm{BE}$ & $53.72 \mathrm{CE}$ & $55.41 \mathrm{~B}$ \\
\hline Humic acid (0.2\%) & $59.38 \mathrm{AB}$ & $57.91 \mathrm{AC}$ & $57.70 \mathrm{AC}$ & 55.68 AD & $54.73 \mathrm{BE}$ & $57.08 \mathrm{~A}$ \\
\hline Biofertile (2\%) & $60.31 \mathrm{~A}$ & $59.49 \mathrm{AB}$ & $58.88 \mathrm{AB}$ & $56.90 \mathrm{AD}$ & $56.49 \mathrm{AD}$ & 58.41 A \\
\hline Control & $56.21 \mathrm{AD}$ & $54.62 \mathrm{BD}$ & $52.30 \mathrm{CE}$ & $51.00 \mathrm{DE}$ & $48.22 \mathrm{E}$ & 52.47 C \\
\hline Means & 58.26 A & $57.20 \mathrm{AB}$ & 56.07 AB & $54.40 \mathrm{BC}$ & $53.29 \mathrm{C}$ & \\
\hline \multicolumn{7}{|c|}{ season $2017 / 2018$} \\
\hline $\begin{array}{l}\text { Seaweed extracts }(0.2 \\
\%)\end{array}$ & $58.26 \mathrm{BF}$ & $57.88 \mathrm{CF}$ & $57.02 \mathrm{DG}$ & $56.22 \mathrm{FH}$ & $54.82 \mathrm{FH}$ & $56.84 \mathrm{C}$ \\
\hline Humic acid (0.2\%) & $61.00 \mathrm{AC}$ & $59.81 \mathrm{AD}$ & $59.30 \mathrm{AE}$ & 57.31 DG & 56.33 DG & $58.75 \mathrm{~B}$ \\
\hline Biofertile (2\%) & $62.51 \mathrm{~A}$ & $61.71 \mathrm{AB}$ & $61.08 \mathrm{AC}$ & $59.13 \mathrm{AE}$ & $58.69 \mathrm{BE}$ & $60.62 \mathrm{~A}$ \\
\hline Control & $57.04 \mathrm{DG}$ & $55.97 \mathrm{EH}$ & $54.12 \mathrm{GI}$ & $52.68 \mathrm{HI}$ & $50.75 \mathrm{I}$ & 54.11 D \\
\hline Means & $59.70 \mathrm{~A}$ & $58.84 \mathrm{AB}$ & 57.88 BC & $56.33 \mathrm{CD}$ & $55.15 \mathrm{D}$ & \\
\hline
\end{tabular}

Color (b value)

Data in Table (9) showed that the b value of fruits was significantly decreased with the progress of storage period in the two seasons. These results were in agreement with Gad EL-Rab (2013). Concerning the effect of pre-harvest treatments, results indicated that $b$ value of fruits was significantly affected by pre-harvest treatments, the highest $b$ value were detected in sweet pepper fruit obtained from biofertile or humic acid (HA) indicating light yellowing color with no significant difference between them in the first season, while the lowest ones were obtained from fruits obtained from untreated plants (control), indicated yellow color. These results were true in the two seasons and in agreement with Gad EL-Rab (2013).Concerning the interaction between pre-harvest treatments and storage period. After 28 days of storage fruits obtained from plants treated with biofertile or humic acid had the highest $b$ value indicating that light yellowing of fruits during storage, fended, the color of sweet pepper fruits was maintained, however, 
fruits obtained from untreated control had the lowest $\mathrm{b}$ value indicating yellow color of fruits. These results were true in the two seasons and in agreements with Gad EL-Rab (2013).

Table 9. Effect of some bio-stimulants on color (b. value) of sweet pepper fruits during storage in 2016-2017 and 2017-2018 seasons.

\begin{tabular}{|c|c|c|c|c|c|c|}
\hline \multicolumn{7}{|c|}{ Storage period in days } \\
\hline Treatments & Start & 7 & 14 & 21 & 28 & means \\
\hline \multicolumn{7}{|c|}{ season $2016 / 2017$} \\
\hline Seaweed extracts $(0.2 \%)$ & $36.32 \mathrm{AD}$ & $35.00 \mathrm{BF}$ & $34.25 \mathrm{DG}$ & $33.50 \mathrm{EH}$ & $32.10 \mathrm{GI}$ & $34.23 \mathrm{~B}$ \\
\hline Humic acid $(0.2 \%)$ & $37.11 \mathrm{AC}$ & $36.50 \mathrm{AD}$ & $35.95 \mathrm{AE}$ & $35.40 \mathrm{AF}$ & $34.53 \mathrm{CG}$ & $35.90 \mathrm{~A}$ \\
\hline Biofertile (2\%) & $38.04 \mathrm{~A}$ & $37.54 \mathrm{AB}$ & $37.01 \mathrm{AC}$ & $36.48 \mathrm{AD}$ & $35.10 \mathrm{BF}$ & $36.83 \mathrm{~A}$ \\
\hline Control & $33.24 \mathrm{FH}$ & $31.43 \mathrm{HI}$ & $30.50 \mathrm{I}$ & $29.57 \mathrm{IJ}$ & $27.68 \mathrm{~J}$ & $30.48 \mathrm{C}$ \\
\hline Means & 36.18 A & $35.12 \mathrm{AB}$ & $34.43 \mathrm{BC}$ & $33.74 \mathrm{C}$ & 32.35 D & \\
\hline \multicolumn{7}{|c|}{ season $2017 / 2018$} \\
\hline Seaweed extracts $(0.2 \%)$ & $33.10 \mathrm{DF}$ & $32.44 \mathrm{EG}$ & $31.78 \mathrm{FH}$ & $30.20 \mathrm{HI}$ & $28.70 \mathrm{IJ}$ & $31.24 \mathrm{C}$ \\
\hline Humic acid $(0.2 \%)$ & $35.20 \mathrm{AC}$ & $34.32 \mathrm{BD}$ & $33.43 \mathrm{CF}$ & $33.00 \mathrm{DF}$ & $32.10 \mathrm{FG}$ & 33.61 B \\
\hline Biofertile (2\%) & $36.40 \mathrm{~A}$ & $35.83 \mathrm{AB}$ & $35.26 \mathrm{AC}$ & $34.00 \mathrm{BE}$ & $33.20 \mathrm{DF}$ & $34.94 \mathrm{~A}$ \\
\hline Control & $31.00 \mathrm{GH}$ & $30.05 \mathrm{HI}$ & $29.10 \mathrm{I}$ & $27.08 \mathrm{~J}$ & $25.10 \mathrm{~K}$ & 28.47 D \\
\hline Means & $33.92 \mathrm{~A}$ & $33.16 \mathrm{AB}$ & $32.39 \mathrm{~B}$ & $31.07 \mathrm{C}$ & 29.77 D & \\
\hline
\end{tabular}

Means in the same column having the same letter are not significantly different at 0.05 level by Duncan's multiple rang test.

\section{Fruit firmness}

Data in Table (10) show that there was a significant reduction in fruit firmness by the prolongation of storage period in both seasons. Similar results were reported by Gad EL-Rab (2013) on pepper fruits. The decline in fruit firmness may be due to the gradually breakdown of proto-pectin to lower molecular fractions which are more soluble in water and this directly correlated with the rate of softening of the fruits (Wills et al., 1998). All preharvest treatments had significantly greater fruit firmness as compared with fruit obtained from untreated plants during storage. However, fruits obtained from biofertile and humic acid were the most effective treatments in reducing the loss of fruit firmness with no significant differences between them in the two seasons, whereas, the highest losses of fruit firmness were found in untreated plants (control). These results may be due to seaweed extracts, humic acid or biofertile increased available of potassium and calcium in the soil (Hanafy et al., 2010) for humic acid, Abou El-Yazied et al., 2012) for seaweed extracts and Singh and Singh (2009) on biofertile and in turn increased these elements in the fruits which increased the osmotic potential and water uptake and allowed less water loss which has impact on fruit firmness (Epstein, 1972). In general, the interaction between pre-harvest treatments and storage period was significant in both seasons. Sweet pepper fruits obtained from plants treated with biofertile or humic acid had the highest values of fruit firmness with no significant differences between them during all storage period, while the lowest ones were recorded in fruits obtained from untreated plants.

Table 10. Effect of some bio-stimulants on firmness $\left(\mathrm{Kg} / \mathrm{cm}^{2}\right)$ of sweet pepper fruits during storage in 20162017 and 2017-2018 seasons.

\begin{tabular}{|c|c|c|c|c|c|c|}
\hline \multirow{2}{*}{ Treatments } & \multicolumn{5}{|c|}{ Storage period in days } & \multirow{2}{*}{ means } \\
\hline & Start & 7 & 14 & 21 & 28 & \\
\hline \multicolumn{7}{|c|}{ season $2016 / 2017$} \\
\hline $\begin{array}{l}\text { Seaweed extracts }(0.2) \\
\%\end{array}$ & $1.75 \mathrm{AC}$ & $1.71 \mathrm{AE}$ & $1.45 \mathrm{CH}$ & $1.23 \mathrm{FI}$ & $1.12 \mathrm{GI}$ & $1.45 \mathrm{~B}$ \\
\hline Humic acid (0.2\%) & $1.95 \mathrm{AB}$ & $1.83 \mathrm{AC}$ & $1.62 \mathrm{BF}$ & $1.42 \mathrm{CH}$ & $1.26 \mathrm{EI}$ & $1.62 \mathrm{AB}$ \\
\hline Biofertile (2\%) & $2.08 \mathrm{~A}$ & $1.95 \mathrm{AB}$ & $1.75 \mathrm{AD}$ & $1.62 \mathrm{BF}$ & $1.48 \mathrm{CG}$ & $1.78 \mathrm{~A}$ \\
\hline Control & $1.50 \mathrm{BG}$ & $1.40 \mathrm{CH}$ & $1.32 \mathrm{DH}$ & $1.00 \mathrm{HI}$ & $0.83 \mathrm{I}$ & $1.21 \mathrm{C}$ \\
\hline Means & $1.82 \mathrm{~A}$ & $1.72 \mathrm{AB}$ & $1.53 \mathrm{BC}$ & $1.32 \mathrm{CD}$ & $1.17 \mathrm{D}$ & \\
\hline \multicolumn{7}{|c|}{ season $2017 / 2018$} \\
\hline $\begin{array}{l}\text { Seaweed extracts }(0.2 \\
\%)\end{array}$ & $2.11 \mathrm{AD}$ & $1.96 \mathrm{BD}$ & $1.70 \mathrm{DF}$ & $1.62 \mathrm{DG}$ & $1.45 \mathrm{EH}$ & $1.77 \mathrm{~B}$ \\
\hline Humic acid (0.2\%) & $2.27 \mathrm{AB}$ & $2.15 \mathrm{ABC}$ & $2.00 \mathrm{AD}$ & $1.90 \mathrm{BD}$ & $1.61 \mathrm{DG}$ & $1.99 \mathrm{~A}$ \\
\hline Biofertile (2\%) & $2.40 \mathrm{~A}$ & $2.28 \mathrm{AB}$ & $2.15 \mathrm{AC}$ & $2.00 \mathrm{AD}$ & $1.70 \mathrm{CF}$ & $2.11 \mathrm{~A}$ \\
\hline Control & $1.89 \mathrm{BE}$ & $1.62 \mathrm{DG}$ & $1.42 \mathrm{FH}$ & $1.18 \mathrm{GH}$ & $1.05 \mathrm{H}$ & $1.43 \mathrm{C}$ \\
\hline Means & $2.17 \mathrm{~A}$ & $2.00 \mathrm{AB}$ & $1.82 \mathrm{BC}$ & 1.68 CD & $1.45 \mathrm{D}$ & \\
\hline
\end{tabular}

Means in the same column having the same letter are not significantly different at 0.05 level by Duncan's multiple rang test. 
Total soluble solids percentage

Data in Table (11) demonstrate that total soluble solids $\%$ of sweet pepper fruits were significant decreased with the prolongation of the storage period in the two seasons. Similar results were obtained by El-Sheikh et al. (1997), on sweet pepper. The reduction in TSS during the storage might owe much to the higher rate of sugar loss through respiration than water loss through transpiration (Wills et al., 1998). There were significant differences between all pre-harvest treatments and untreated control on TSS\% of fruits during storage. Sweet pepper fruits obtained from plants treated with biofertile or humic acid were the most effective treatments in maintaining TSS\% with no significant differences between them in the first season. While the lowest ones in this concern were recorded for fruits obtained from untreated control. Fruits obtained from seaweed extract were less effective in this concern. These results were true in the two seasons and were in agreement with those obtained by Khreba et al. (2014) for HA and Hassan and Emam (2015) for biofertile. In general, the interaction between pre-harvest treatments and storage period was significant in the two seasons. After 28 days of storage, data revealed that sweet pepper fruits obtained from plants treated with biofertile or humic acid gave the highest value of TSS\% with no significant differences in the two seasons, while the lowest ones were found in those obtained from untreated control at the same period of storage

Table 11. Effect of some bio-stimulants on TSS percentage of sweet pepper fruits during storage in 2016-2017 and 2017-2018 seasons.

\begin{tabular}{|c|c|c|c|c|c|c|}
\hline \multirow{2}{*}{ Treatments } & \multicolumn{5}{|c|}{ Storage period in days } & \multirow{2}{*}{ means } \\
\hline & Start & 7 & 14 & 21 & 28 & \\
\hline & \multicolumn{5}{|c|}{ season $2016 / 2017$} & \\
\hline Seaweed extracts $(0.2 \%)$ & $7.60 \mathrm{BF}$ & $7.47 \mathrm{CF}$ & $6.97 \mathrm{FH}$ & $6.20 \mathrm{HJ}$ & $5.50 \mathrm{JK}$ & $6.75 \mathrm{~B}$ \\
\hline Humic acid $(0.2 \%)$ & $8.40 \mathrm{AB}$ & $8.20 \mathrm{AC}$ & $7.80 \mathrm{AE}$ & 7.30 DG & $6.60 \mathrm{GI}$ & $7.66 \mathrm{~A}$ \\
\hline Biofertile (2\%) & $8.50 \mathrm{~A}$ & $8.43 \mathrm{~A}$ & $8.00 \mathrm{AD}$ & $7.47 \mathrm{CF}$ & $7.00 \mathrm{EH}$ & $7.88 \mathrm{~A}$ \\
\hline Control & $6.80 \mathrm{FH}$ & $6.80 \mathrm{FH}$ & $6.30 \mathrm{HJ}$ & $5.83 \mathrm{IJK}$ & $5.10 \mathrm{~K}$ & 6.17 C \\
\hline \multirow[t]{2}{*}{ means } & $7.83 \mathrm{~A}$ & $7.73 \mathrm{~A}$ & $7.27 \mathrm{~B}$ & $6.70 \mathrm{C}$ & 6.05 D & \\
\hline & \multicolumn{5}{|c|}{ season $2017 / 2018$} & \\
\hline Seaweed extracts $(0.2 \%)$ & $7.10 \mathrm{CF}$ & 6.97 DG & $6.60 \mathrm{EH}$ & $6.03 \mathrm{HJ}$ & $5.27 \mathrm{JL}$ & $6.39 \mathrm{C}$ \\
\hline Humic acid (0.2\%) & $8.10 \mathrm{AB}$ & $7.90 \mathrm{AC}$ & 7.50 BD & 7.00 DF & $6.47 \mathrm{FI}$ & $7.39 \mathrm{~B}$ \\
\hline Biofertile (2\%) & $8.53 \mathrm{~A}$ & $8.33 \mathrm{AB}$ & $7.90 \mathrm{AC}$ & 7.47 BE & $7.17 \mathrm{CF}$ & $7.88 \mathrm{~A}$ \\
\hline Control & $6.10 \mathrm{GJ}$ & $6.33 \mathrm{FI}$ & $5.60 \mathrm{IK}$ & $5.13 \mathrm{KL}$ & $4.40 \mathrm{~L}$ & $5.51 \mathrm{D}$ \\
\hline means & $7.47 \mathrm{~A}$ & $7.38 \mathrm{~A}$ & $6.90 \mathrm{~B}$ & $6.41 \mathrm{C}$ & $5.83 \mathrm{D}$ & \\
\hline
\end{tabular}

Means in the same column having the same letter are not significantly different at 0.05 level by Duncan's multiple rang test.

\section{Ascorbic acid content}

Data in Table (12) show that ascorbic acid content of sweet pepper fruits were decreased with the prolongation of the storage period in both seasons, these results are similar with those obtained by Ibrahim and Abdullah (2018). The reduction of ascorbic acid content during storage might owe much to great metabolic activity during storage as it is respired Wills et al., (1981). Sweet pepper fruits obtained from plants treated with all pre-harvest treatments had significantly the highest value of ascorbic acid content in fruits as compared with those obtained from untreated plants during storage. However, fruits obtained from biofertile were the most effective treatments in maintaining ascorbic acid content as compared with the other treatments or untreated plants during storage in the two seasons, followed by humic acid or seaweed extracts with no significant differences between them in the two seasons. Fruits obtained from untreated plants showed the lowest ones on ascorbic acid content during storage. These results were in agreement with those obtained by Khreba et al. (2014) for HA, Hassan and Emam (2015) for biofertile and Gad ELRab (2018) for seaweed extract or humic acid. In general, the interaction between pre-harvest treatments and storage period was significant in the two seasons. After 28 days of storage, data revealed that all pre-harvest treatments had the highest value of ascorbic acid content with no significant differences between them in the two seasons, while fruits obtained from untreated plants (control) had the lowest ones in this concern. 
Table 12. Effect of some bio-stimulants on ascorbic acid content $(\mathrm{mg} / 100 \mathrm{~m} \mathrm{FW})$ of sweet pepper fruits during storage in 2016-2017 and 2017-2018 seasons.

\begin{tabular}{|c|c|c|c|c|c|c|}
\hline \multirow{2}{*}{ Treatments } & \multicolumn{5}{|c|}{ Storage period in days } & \multirow[b]{2}{*}{ means } \\
\hline & Start & 7 & 14 & 21 & 28 & \\
\hline & \multicolumn{5}{|c|}{ season $2016 / 2017$} & \\
\hline Seaweed extracts $(0.2 \%)$ & $288.20 \mathrm{AD}$ & $285.10 \mathrm{AE}$ & $261.80 \mathrm{GJ}$ & $250.50 \mathrm{IK}$ & $244.80 \mathrm{JL}$ & $266.10 \mathrm{~B}$ \\
\hline Humic acid $(0.2 \%)$ & $294.80 \mathrm{AB}$ & 293.80 AC & $265.20 \mathrm{FI}$ & $255.00 \mathrm{HK}$ & $248.20 \mathrm{IK}$ & 271.40 B \\
\hline Biofertile (2\%) & $299.20 \mathrm{~A}$ & $296.40 \mathrm{AB}$ & $276.50 \mathrm{CG}$ & $268.60 \mathrm{EH}$ & $260.50 \mathrm{GJ}$ & $280.20 \mathrm{~A}$ \\
\hline Control & $279.50 \mathrm{BF}$ & $274.00 \mathrm{DG}$ & $253.00 \mathrm{HK}$ & $240.00 \mathrm{KL}$ & $226.00 \mathrm{M}$ & $254.50 \mathrm{C}$ \\
\hline \multirow{2}{*}{ means } & $290.40 \mathrm{~A}$ & $287.30 \mathrm{~A}$ & 264.10 B & $253.50 \mathrm{C}$ & $244.88 \mathrm{C}$ & \\
\hline & \multicolumn{5}{|c|}{ season $2017 / 2018$} & \\
\hline Seaweed extracts $(0.2 \%)$ & $291.30 \mathrm{AD}$ & $288.20 \mathrm{AE}$ & $264.90 \mathrm{FI}$ & $253.60 \mathrm{HJ}$ & $247.90 \mathrm{IK}$ & $269.20 \mathrm{~B}$ \\
\hline Humic acid $(0.2 \%)$ & $298.90 \mathrm{AB}$ & $297.80 \mathrm{AC}$ & $269.40 \mathrm{FH}$ & $259.20 \mathrm{GJ}$ & $252.40 \mathrm{HJ}$ & 275.50 B \\
\hline Biofertile (2\%) & $303.70 \mathrm{~A}$ & $300.90 \mathrm{~A}$ & $281.00 \mathrm{CF}$ & $273.10 \mathrm{EG}$ & $265.00 \mathrm{FI}$ & $284.70 \mathrm{~A}$ \\
\hline Control & $281.80 \mathrm{BF}$ & 276.30 DG & $255.30 \mathrm{HJ}$ & $242.30 \mathrm{JK}$ & $228.30 \mathrm{~L}$ & $256.80 \mathrm{C}$ \\
\hline means & $293.90 \mathrm{~A}$ & 290.80 A & 267.60 B & $257.00 \mathrm{C}$ & $248.40 \mathrm{C}$ & \\
\hline
\end{tabular}

Means in the same column having the same letter are not significantly different at 0.05 level by Duncan's multiple rang test.

\section{References}

A.O.A.C. 2000. Association of Official Analytical Chemists. Washington DC. International 17th Edition, Revision I.

Abd El-Basir, A.E., 2013. Role of some biostimulants and anti-stressors to mitigate high temperature damages on sweet pepper. Ph.D. Thesis, Fac. Agric., Suez Canal Univ., Ismailia, Egypt, 206p.

Abou El-Yazied, A.; A.M. El-Gizawy; M.I. Ragab and E.S. Hamed, 2012. Effect of seaweed extract and compost treatments on growth, yield and quality of snap bean. J. of American Sci., 8(6):120.

Ali, M.S.; M.A. Hamza; G. Amin; M. Fayez; M. ELTahan and M. Monib, 2005. Production of biofertilizers using baker's yeast effluent and their application to wheat and barley grown in north Sinai deserts. Arch Agron and Soil Sci., 51:589-604.

Al-Sahaff, F.H.R., 1989. Applied plant nutrition. AlHekma House, Baghdad University, Ministry of Higher Education, Iraq (In Arabic).

Anantharaj, M.J. and V.Y. Venkatesalu, 2002. Studies on the effect of seaweed extracts on Dolichos biflorus. Seaweed Res. Utiln., 24 (1):129-137.

Atiyeh, R.M.; S. Lee and C.A. Edwards, 2002. The influence of humic acids derived from earthworm-processed organic wastes on plant growth. Bioresearch Technology, 84: 7-14.

Awasthi, R.P.; R.K. Godara and N.S. Kaith, 1998. Interaction effect of VA-mycorrhizae and Azotobacter inoculation on micronutrient uptake by peach seedlings. J. Hort., 11: 1-5.

Banaras, M.; P.W. Bosland and N.K. Lownds, 2005. Effects of harvest time and growth conditions on storage and post-storage quality of fresh peppers ( Capsicum annuum L.). Pak. J. Bot., 37 (2):337344.
Blunden, G.; T. Jenkins and Y.W. Liu, 1996. Enhanced chlorophyll levels in plants treated with seaweed extract. J. Appl. Phycol., 8: 535-543.

Booth, E., 1965. The manurial value of seaweeds. Bot. Mar., 8: 138-143.

Booth, E., 1969. The manufacture and properties of liquid seaweed extracts. Proc. Int. Seaweed Symp., 6: 655-662.

Challen, S.B. and J.C. Hemingway, 1965. Growth of higher plants in response to feeding with seaweed extracts. Proc. 5 Ind. Seaweed Symp. Halifaxth . August 25-28.

Demir, N.L.; B.R. Dural and Y.S. Kevser, 2006. Effect of seaweed suspensions on seed germination of tomato, pepper and aubergine. J. Bio. Sci., 6(6):1130-1138.

El-Sheikh, T.M.; S.Z. Abd El-Rahman and S.M. Hassanen, 1997. Effect of calcium chloride and hydrated lime on keeping quality of sweet pepper and cucumber fruits. Annals Agric. Sci., Moshtohor, 35(4):2371-2389.

Epstein, E., 1972. Mineral nutrition of plants principles and perspectives. Joh,Willy and Sons, Inc., New Uork, 412 p.

Fathima, P.S. and G.R. Denesh, 2013. Influence of humic acid spray on growth and yield of chilli (Capsicum annum L.). International Journal of Agricultural Sciences, 9(2):542-546.

Gad El-Hak, S.H.; A.M. Ahmed and Y.M.M. Moustafa, 2012. Effect of foliar application with two antioxidants and humic acid on growth, yield and yield components of peas (Pisum sativum L.). Journal of Horticultural Science \& Ornamental Plants, 4(3):318-328.

Gad EL-Rab, N.A., 2013. Effect of some pre and postharvest treatments on yield, quality and storability of sweet pepper. M.Sc. Thesis, Fac. Agric., Cairo Univ., Cairo, Egypt, 138 p.

Gad EL-Rab, N.A., 2018. Effect of some pre and postharvest treatments on yield, quality and storability of snap beans. Ph.D. Thesis, Fac. Agric., Cairo Univ., Cairo, Egypt, 252 p. 
Gallon, J.R. and J.T. Wright, 2006. Limited grazing pressure by native herbivores on the envasive seaweed caulerba. J. Australia Estuary Marine and Fresh Water Res., 57(7):685-694.

Halime, O.U.; U. Husnu; K.Yasar and P. Huseyin, 2011. Changes in fruit yield and quality in response to foliar and soil humic acid application in cucumber. Scientific Research and Essays, 6(13): 2800-2803.

Hamza, M.A.; H.Youssef; A. Helmy; G.A. Amin; M. Fayez and A. Higazy, 1994. Mixed cultivation and inoculation of various genera of associative diazotrophs. In: Hegazi N.A., Fayez M., Monib M.,editors. Nitrogen fixation with non-legumes. The American University in Cairo Press; Cairo, Egypt: pp.319-326.

Hanafy, A.A.H.; M.R. Nesiem; A.M. Hewedy and H. Sallam, 2010. Effect of some simulative compounds on growth, yield and chemical composition of snap bean plants grown under calcareous soil conditions. Journal of American Science, 6(10): 552-569.

Hassan, A.H. and M.S. Emam, 2015. Improving fruit quality and storability of strawberry fruits by using pre and postharvest treatments. Journal of American Science, 11(1): 44-60.

Hegazi, N.A. and M. Fayez, 2003. Biodiversity and endophytic nature of diazotrophs other than rhizobia associated to non-leguminous plants of semi-arid environments. Arch Agron Soil Sci., 49:213-235.

Ibrahim, H.A. and M.A.A. Abdullah, 2018. Effects of 1-Methylcyclopropane on quality of tomato and sweet pepper fruits during mixed loads. Bioscience Research, 15(1): 270-279.

Karakurt, Y.; H. Unlu; H. Unlu and H. Padem, 2009. The influence of foliar and soil fertilization of humic acid on yield and quality of pepper. Acta Agriculturae Scandinavica Section B Plant Soil Science, 59 (3): 233- 237.

Khan, W.; U.P.Rayirath; S. Subramanian; M.N. Jithesh; P. Rayorath; D.M. Hodges; A.T. Critchley; J.S. Craigie; J. Norrie and B. Prithiviraj, 2009. Seaweed extracts as biostimulants of plant growth and development. J. Plant Growth Regul., 28:386-399.

Khreba, A.H.; A.H. Hassan; M.S. Emam and S.A. Atalam 2014. Effect of some pre and postharvest treatments on quality and storability of strawberry fruits. Journal of American Science, 10(11):239248.

Kim, M.K.; K.M. Choi; C.R.Yin; K.Y. Lee; W.T. Im; J.H. Lim and S.T. Lee, 2004. Odorous swine wastewater treatment by purple non-sulfur bacteria, Rhod pseudomonas palustris, isolated from eutrophicated ponds. Biotechnol. Lett., 26(10):819-822.

Marhoon, I.A. and M.K. Abbas, 2015. Effect of foliar application of seaweed extract and amino acids on some vegetative and anatomical characters of two sweet pepper (Capsicum Annuum L.) cultivars. International Journal of Research Studies in Agricultural Sciences, 1 (1): 35-44.

Marwaha, B.C., $1995 . \quad$ Biofertilizers-A, supplementary source of plant nutrient. Fertilizer News, 40: 39-50.

Mc Collum, J.P., 1980. Producing Vegetable Crop 3rd ed. The Interstate Printer and Publisher. USA., P. 607.

McGuire, R.G. 1992. Reporting of objective color measurements. HortScience, 27: 1254- 1255.

Mikkelsen, R.L., 2005. Humic materials for agriculture. Better crops, 89 (3):6-10.

Mishustin, E.N., 1970. The importance of nonsymbiotic nitrogen fixing microorganisms in agriculture. Plant and Soil, 32(3): 545-554.

Mohammed, G.H., 2013. Effect of amino acids and ascorbic acid on growth, yield and fruits quality of pepper (Capsicum annum L). Int. J. Pure Appl. Sci. Technol., 17(2): 9-16.

Murugalakshmikumari, R.I.; V.T. Ramasubramanian and K.F. Muthuchezhian, 2002. Studies on the utilization of seaweed on the utilization of seaweed as an organic fertilizer on the growth and some biochemical characteristics of black gram and cucumber. J. Seaweed Res. Utiln., 24 (1): 125-128.

Nagodawithana, W.T., 1991. Yeast Technology. Universal Foods Corporation Milwaukee, Wisconisn. Published by Van Nostrand Reinhold New York. Ind. J. Exp. Boil., 2:149-152.

Narula, N. and K.G. Gupta, 1986. Ammonia excretion by Azotobacter chroococcum in liquid culture and soil in the presence of manganese and clay minerals. Plant and Soil, 93: 205-209.

Neill, S.J.; R. Desikan; A. Clarke; R.D. Hurst and J. Hancock, 2002. Hydrogen peroxide and nitric oxide as signaling molecules in plants. J. Exp. Bot., 53 (372):1237-1247.

Nuruzzaman, M.; M. shrafuzzarnan; M.Z. Islam and M.R. Islam, 2003. Effect of biofertilizers on vegetative growth of okra. Korean J. Crop Sci., 48(2): 73-80.

Othman, A.A.; W.M. Amer; M. Fayez; M. Monib and N.A. Hegazi, 2003. Biodiversity of diazotrophs associated to the plant cover of north Sinai deserts. Arch Agron Soil Sci., 49:683-705.

Othman, A.A.; W.M. Amer; M. Fayez and N.A. Hegazi, 2004. Rhizosheath of Sinai desert plants is a potential repository for associative diazotrophs. Microbiol Res., 159: 285-293.

Prasad, K.D.; A.K. Das; M.D. Oza; H.A. Brahmbhatt; A.R. Siddhanta; K.E. Eswaran; M.R. Rrajyaguru and P.K. Ghosh, 2010. Detection and quantification of some plant growth regulators in a seaweed based foliar spray employing mass spectrometric technique. J. Agric. Food Chem., 58:4594-4601. 
Rao, V.R.R.; J.L.N. Rao and T.K. Adhya, 1986. Heteropophic nitrogen fixation as influenced by fertilizers in rice soil system; in Cereal Nitrogen Fixation (India: ICRISAT)

Sarig, S.; A. Blum and Y. Okon. 1988. Improvement of water status and yield of grown grain sorghum by inoculation with A. brasilense. J. Agric. Sci., 110:271-278.

Selim, E.M.; A.S. El-Neklawy and S.M. El-Ashry, 2010. Beneficial effects of humic substances on soil fertility to fertigated potato grown on sandy soil. Libyan Agriculture Research Center Journal International, 1 (4): 255-262.

Senn, T.L., 1991. Humates in Agriculture. Acres USA, Jan.

Serenella, N.; D. Pizzeghelloa; A. Muscolob and A. Vianello, 2002. Physiological effects of humic substances on higher plants. Soil Biol. \& Biochemi., 34: 1527-1536.

Shehata, S.A.; Z.A. Said; M.M. Attia and M.A. Rageh, 2015. Effect of foliar application of micronutrients, magnesium and wrapping films on yield, quality and storability of green bean pods. Fayoum J. Agric. Res. And Dev., 30(1):121-139.

Singh, A. and J.N. Singh. 2009. Effect of biofertilizers and bioregulators on growth, yield and nutrient status of strawberry cv. Sweet Charlie. Indian J. Hort., 66(2): 220-224.

Snedecor, G.W. and W.G. Cochran, 1980. Statistical methods. 8th Ed., Iowa State Univ. Press, Ames, Iowa, USA., $476 \mathrm{p}$.

Terry, E.; M. Pino; A. De Los and N. Medina, 2000. Application times of an Azospirillum bioproduct in tomato growth, development and yield. Cultivos Tropicalles, 21: 5-8.

Waller, R.A. and D.B. Duncan, 1969. A buyes rule for the symmetric multiple comparison problems. Amer. State. Assoc. J., 64:1484-1503.

Wills, H.H.R.; T.H. Lee; D. Graham; W.B. Mc Glasson and E.G. Hall, 1981. An introduction in the physiology and handling of fruits and vegetables. New South Wales University Press Limited Australia, 123-126.

Wills, R.; B. Mcglasson; D. Graham and D. Joyce, 1998. Postharvest: An introduction to the physiology and handling of fruit, vegetables and ornamentals. Wallingford: CAB International, $262 \mathrm{pp}$.

Zhang, X.; E.H. Ervin and R.E. Schmidt, 2003. Physiological effects of liquid applications of a seaweed extract and a humic acid on creeping bent grass. J. Amer. Hort. Sci., 128: 492-496. 